\title{
Efektifitas Model Pembelajaran Inkuiri Berbantuan Media Petaku Terhadap Hasil Belajar Matematika by Ramadhani Putri Praswanti
}

Submission date: 30-Mar-2020 01:41PM (UTC+0700)

Submission ID: 1285122154

File name: i_Berbantuan_Media_Petaku_Terhadap_Hasil_Belajar_Matematika.docx (86.34K)

Word count: 2783

Character count: 17659 


\title{
DIDAKTIKA
}

Jurnal Pendidikan Sekolah Dasar

Volume X, Nomor X, X-X, XXXX

Journal homepage: $h$ ttps://journal.uny.ac.id/index.php/didaktika

\section{Effectiveness of Inquiry Model Assisted With Petaku Media On Mathematics Learning Outcomes}

\author{
Ramadhani Putri Praswanti, ${ }^{凶}$, Henry Suryo Bintoro², Himmatul Ulya ${ }^{3}$ \\ 1 Universitas Muria Kudus, Indonesia
}

\begin{abstract}
The purpose in this study is to know the improvement of learning outcomes aspects of knowledge, and skills namely student activities, and achievement of minimum completeness criteria in the implementation of inquiry models with petaku media on the skala theory. This research was conducted in two elementary schools in the Kudus country. The Subject in this research totaling 67 students and conducted in three meetings. 1 here are two variables, the independent variable is inquiry learning model with colaboration petaku media, and the dependent variable used is student learning outcomes in aspect of knowledge and students learning activities. The research is an experi 1ental quantitative. The results showed that there was an increase in mathematics learning outcomes before and after the implementation of the inquiry learning model, which was indicated N-Gain test with increase of 0,69 and included in the category of moderate improvement. Students activities taught experimental class and control class there is also a difference, with a significance value that appears in the Mann-Whitney test that is equal to 0,037 which can be interpreted that learning activities in the experimental class are better than the control class. Learning ini experimental class also reached the classical and individual completeness criteria, the output of the result of individual learning completeness indicated by the One-Sample T Test with a significance level of 0,001 , more than $75 \%$ of the students completed in learning.
\end{abstract}

Keywords: Inquiry Model, Mathematic Learning Outcomes, Petaku Media

\section{Efektifitas Model Pembelajaran Inkuiri Berbantuan Media Petaku Terhadap Hasil Belajar Matematika}

\section{Abstrak}

Penelitian ini bertujuan untuk mengetahui peningkatan hasil belajar siswa pada aspek pengetahuan, dan keterampilan yakni aktivitas belajar siswa, dan pencapaian kriteria ketuntasan minimal dalam pengimplementasian model inkuiri dengan bantuan media petaku pada materi skala. Penelitian ini dilaksanakan di dua sekolah dasar di Kabupaten Kudus. Subjek dalam penelitian ini sebanyak 67 siswa dan dilaksanakan dalam tiga kali pertemuan. Terdapat dua variabel, vâlabel bebasnya yakni model inkuiri dengan bantuan media petaku, dan variabel terikat yang digunakan yakni hasil belajar siswa pada aspek pengetahuen dan aktivitas belajar siswa. Jenis penelitian ini adalah penelitian kuantitatif. Hasil penelitian menujukkan bahwa terdapat peningkatan hasil belajar matematika sebelum dan sesudah diterapkannya model pembelajaran inkuiri dengan bantuan media petaku yang ditunjukkan dengan uji N-Gain dengan peningkatan sebesar 0,69 dan masuk dalam kategori peningkatan sedang. Aktivitas belajar antara siswa pada kelas eksperimen dan kelas kontrol juga terdapat perbedaan, dengan nilai signifikansi yang muncul dalam uji Mann-Whitney yaitu sebesar 0,037 yang mana dapat diartikan bahwa aktivitas belajar pada kelas kontrol tidak lebih baik dari kelas eksperimen. Pembelajaran di kelas eksperimen juga mecapai pada kriteria ketuntasan klasikal maupun individual, output hasil uji ketuntasan belajar individual yang dtunjukkan oleh uji One Sample T Test dengan taraf signifikansi 0,001 dan lebih dari $75 \%$ siswa tuntas dalam pembelajaran.

Kata kunci: model inkuiri, hasil belajar matematika, aktivitas belajar.

Corresponding Author:

Affiliation Addres: Kampus UMK Gondangmanis, Bae Kudus Gd. L It I PO. BOX 53 Kudus

E-mail: ramramadhani15@gmail.com 


\section{PENDAHULUAN}

Kemendikbud RI menerapkan kurikulum terbaru yakni kurikulum 2013 yang mana pada penerapannya setiap mata pelajaran diintegrasikan dengan mata pelajaran lainnya. Namun hal tersebut tidak berlaku dengan mata pelajaran matematika kelas tinggi sekolah dasar. Pengimplementasian muatan matematika pada kelas tinggi terpisah dengan muatan pelajaran lainnya atau dengan kata lain tidak diintegrasikan dengan muatan lainnya. Pemisahan muatan matematika dengan muatan lainnya ini disebebakan muatan matematika pada kelas tinggi memerlukan penjelasan serta pemahaman yang mendalam.

Berdasarkan hasil survey The Programme for International Students Assessment (PISA) terhadap prestasi siswa sekolah di seluruh dunia yang dilakukan pada tahun 2018 didapatkan hasil yang rendah yakni Indonesia menempati peringkat ke 74 dari total keseluruhan 79 negara yang ikut berpartisipasi, dengan skor PISA 379 (OECD, 2018). Mengacu pada skor PISA tahun 2018 ini terdapat penurunan skor PISA di Negara kita dibanding pada hasil PISA tahun lalu. Hal ini merupakan tantangan dunia pendidikan Indonesia agar dapat meningkatkan peringkat Indonesia dalam ajang PISA tahun selanjutnya.

Menurunnya perolehan skor Indonesia dalam PISA ini disebabkan beberapa faktor yang ada selama pembelajaran formal di sekolah. Ayuwanti (2016) mengatakan bahwa hasil belajar matematika siswa yang rendah dikarenakan peserta didik memiliki anggapan bahwa matematika merupakan pelajaran yang menjadi momok menakutkan, sehingga pelajaran matematika sulit diterima dan bermakna bagi siswa. Proses pembelajaran yang dilakukan di sekolah saat ini masih berorientasi pada pengajar dan siswa hanya diletakkan sebagai subjek selama proses pembelajaran. Kegiatan 1 belajar pun masih mengacu dengan LKS yang disediakan dan kurang memperhatikan lingkungan sekitar siswa sebagai bahan untuk belajar. Hal senada 119a dikemukakan oleh Rohmah (2017) bahwa metode konvensional yang masih diterapkan sekolah dalam pembelajaran menjaikan siswa pasif dan tidak menggunakan kemampuan berikir secara penuh dalam pembelajaran.
Permasalahan dalam pembelajaran matematika juga dirasa sama dengan proses pembelajaran matematika dibanyak sekolah dasar, salah 1 satunya pada pembelajaran matematika kelas V SD 1 Prambatan Kidul. Penggunaan metode konvensional dalam pembelajaran yang dilakukan oleh guru kelas berupa ceramah, pemberian tugas, dan tanya jawab ini menjadikan siswa jenuh selama proses pembelajaran berlangsung. Hal ini menjadikan citra dari pelajaran matematika sebagai pelajaran yang tidak menarik dan membosankan untuk dipelajari. Hal ini menyebabkan nilai ulangan harian matematika siswa di SD ini memiliki rata-rata 66,45 dengan KKM yang ditetapkan sekolah yakni 70 .

Proses pembelajaran yang sama terjadi juga pada SD 4 Prambatan Kidul, di mana dalam pembelajaran guru masih menerapkan metode konvensional. Penggunaan metode konvensional yang dilakukan yakni guru menjelaskan materi yang akan disampaikan, kemudian menyajikan rumus dan meminta siswa untuk memahaminya, kemudian siswa diminta untuk mengerjakan latihan soal yang terdapat dalam LKS. Pembelajaran seperti ini menjadikan siswa tidak berpartisipasi penuh dalam pembelajaran, karena siswa tidak difasilitasi untuk tanya jawab. Materi yang disampaikan pun tidak sepenuhnya dapat diserap oleh siswa, hal ini dibuktikan dengan rendahnya nilai ulangan harian matematika siswa pada materi penjumlahan pengurangan pecahan, yakni sebesar 62,31 dan tidak memenuhi KKM atau batas minimal ketuntasan yang telah ditetapkan oleh sekolah.

Berdasarkan hasil obeservasi terseut perlu dilakukan penelitian guna mendapatkan solusi, yakni dengan penerapan model pembelajaran berbasis penemuan (inkuiri) dan dikolaborasikan dengan media petaku. Di mana dalam penerapannya siswa akan dituntut untuk aktif dalam pembelajaran. Pembelajaran matematika pada sekolah dasar Tengan model Inkuiri ini yang dilakukan Israwani (2015), dari hasil penelitian didapatkan bahwa pembelajaran matematika dengan menerapkan model inkuiri dapat meningkatan prestasi belajar matematika peserta didik, aktivitas peserta didik dalam pembelajaran, serta aktivitas guru selama proses pembelajaran. Terdapat beberapa 
kekurangan dalam penelitian tersebut, yakni tidak terdapat penggunaan media dalam pembelajaran. Mengingat penggunaan media dapat meningkatkan efektifitas dalam pembelajaran, penelitian ini akan dikolaborasikan dengan sebuah media pembelajaran dengan nama petaku yakni untuk saran penyampaian materi yang akan diterima oleh siswa.

Model inkuiri ini akan diterpakan menggukanakan langkah-langkah yang dikemukakan Majid (2017: 175) sebagai berikut. 1) orientasi, yaitu pembinaan suasana responsive dalam pembelajaran. Pada tahap ini guru memberikan stimulus kepada peserta didik untuk dapat berpikir memecahkan masalah; 2) merumuskan masalah, merupakan langkah dalam pelibatan peserta didik dalam permasalahan yang mengandng teka-teki sehingga menjadikan siswa tertantang untuk berpikir; 3) merumuskan hipotesis, yakni perumusan hipotesis yang nantinya kebenarannnya akan diuji bersamasama; 4) mengumpulkan data, yakni tujuannya untuk memilih informasi yang dapat digunakan untuk menguji hipotesis yang sudah dirumuskan; 5) menguji hipotesis, yakni penentuan apakah jawaban dapat diterima atau tidak berdasarkan data yang sudah terkumpul; 6) merumuskan kesimpulan, proses terakhir dalam langkah pembelajaran yakni untuk mendeskripsikan temuan yang diperoleh peserta didik didasarkan pada hasil menguji hipotesis.

\section{METODE}

Penelitian ini merupakan penelitian experiment kuantitatif. Pelaksanaan penelitian ini di kelas V pada dua SD, yakni SDN 1 Prambatan Kidul dan SDN 4 Prambatan Kidul Kecamatan Kaliwungu Kabupaten Kudus pada tahun pelajaran 2019/2020. Sampel dalam penelitian ini yakni sebanyak 67 siswa, dengan rincian 33 siswa pada kelas eksperimen, dan 31 siswa pada kelas kontrol. Desain penelitian ini menggunakan Nonequivalent PretestPosttest Control Group Design. Desain penelitian dapat dilihat dalam tabel 1 berikut. Tabel 1. Nonequivalent Pretest-Posttest Control Group Design

\begin{tabular}{|c|c|c|}
\hline $\begin{array}{ll} & O_{1} \\
1 & O_{1}\end{array}$ & $X$ & $\begin{array}{l}\mathrm{O}_{2} \\
\mathrm{O}_{2}\end{array}$ \\
\hline
\end{tabular}

Sumber: Lestari dan Yudhanegara (2018: 138)
Teknik pengumpulan data dalam penelitian ini yakni observasi, wawancara, tes, dan dokumentasi. Untuk teknik analisis data yang digunakan yakni dengan instrumen tes. Instrumen tes yang akan digunakan diuji terlebih dahulu menggunakan uji validitas dan uji reliabilitas insterumen. Analisis data nilai pretest dan posttest meliputi uji normalitas, uji N-Gain, uji Mann Whitney, uji One Sample T Test, dan uji Z. Keseluruhan uji tersebut menggunakan aplikasi SPSS 25 dan program Microsoft Excel 2016.

\section{TEMUAN DAN HASIL PEMBAHASAN}

\section{Analisis Butir Soal}

a. Validitas Soal

Pengujian validitas soal dalam penelitian ini yakni dengan validitas isi dan validtas konstruk. Validitas isi dilakukakn melalui penilaian ahli (expert judgement) yang dilakukan oleh ahli dibidang matematika. Hasil dari validitas ahli sebagai berikut.

Tabel 2. Hasil Validasi Ahli

\begin{tabular}{cllll}
\hline No & Validator & Nilai & Huruf & Keterangan \\
\hline 1 & $\begin{array}{l}\text { Validator } \\
1\end{array}$ & 29,4 & B & $\begin{array}{l}\text { Soal dapat } \\
\text { digunakan } \\
\text { dengan } \\
\text { sedikit revisi }\end{array}$ \\
& & & & $\begin{array}{l}\text { Soal dapat } \\
\text { digunakan } \\
\text { tanpa revisi }\end{array}$ \\
\hline
\end{tabular}

Hasil validasi ahli pada tabel 2 didapatkan nilai rata-rata yakni 32,32 dan berpredikat huruf A. Maka soal yang digunakan dalam penelitian dikategorikan sangat baik dan dapat digunakan tanpa revisi. Setelah dilakukan uji validtas isi, kemudian soal akan diujicobakan kepada 21 siswa kelas VI dan dihitung dengan rumus product moment pearson sebagai berikut.

$$
r_{\mathrm{xy}}=\frac{\mathrm{N} \sum \mathrm{XY}-\left(\sum \mathrm{x}\right)\left(\sum \mathrm{Y}\right)}{\left.\sqrt{\left\{\mathrm{N} \sum \mathrm{x}^{2}\right.}-(\mathrm{x})^{2}\right\}\left\{\mathrm{N} \sum \mathrm{Y}^{2}-(\mathrm{Y})^{2}\right\}}
$$

Sumber: Sugiyono (2016: 356)

Dari perhitungan dengan menggunakan rumus product moment pearson yang dilakukan dengan aplikasi Microsoft Excel 2016 didapatkan 10 soal valid dari 12 soal yang diujicobakan. Ke 10 soal yang valid kemudian akan diuji reliabilitas untuk mengukur ketetatapan instrument.

b. Reliabilitas Soal 
Pengujian reliabilitas dilakukan setelah didapatkan soal yang $\sqrt{1}$ lid dari uji validitas. Uji reliabilitas akan menggunakan rumus Alpha Cronbach sebagai berikut.

$$
r_{11}=\left(\frac{n}{(n-1)}\right)\left(1-\frac{\sum \sigma_{\frac{1}{1}}^{2}}{\sigma_{\frac{2}{1}}^{2}}\right)
$$

Hasil perhitungan dari uji reliabilitas dapat dilihat pada tabel 3 .

Tabel 3. Hasil Reliabilitas Soal

\begin{tabular}{llll}
\hline $\begin{array}{l}\text { Jumlah } \\
\text { siswa }\end{array}$ & $\boldsymbol{R}_{\text {hitung }}$ & $\boldsymbol{R}_{\text {tabel }}$ & Keterangan \\
\hline 21 & 0,79 & 0,43 & Reliabel \\
\hline
\end{tabular}

Didapatkan $\mathrm{R}$ hitung $0,79>\mathrm{R}$ tabel sehingga dapat disimpulkan bahwa soal yang diujicobakan reliabel. Dari sepuluh soal yang reliabel, akan diambil delapan soal untuk digunakan dalam penelitian, yakni sebagai soal pretest dan posttest. Pengambilan 8 dari 10 soal yang dapat diguanakan ini didasarkan pada setiap dua butir soal yang digunakan akan mewakili indikator hasil belajar dalam penelitian.

\section{Uji Normalitas}

Uji normalitas ini bertujuan untuk mengetahui apakah data nilai posttest siswa kelas eksperimen berdistribusi normal atau tidak. Pengujian ini dengan menggunakan SPSS 25. Hasil dari uji normalitas data sebagai berikut.

Tabel 4. Hasil Uji Normalitas

\begin{tabular}{llr}
\multicolumn{2}{c}{ One-Sample Kolmogorov-Smirnov Test } \\
& & $\begin{array}{c}\text { Nilai Postttest } \\
\text { Eksperimen }\end{array}$ \\
\hline $\mathrm{N}$ & 36 \\
Normal & Mean & 172.22 \\
Parameters ${ }^{\mathrm{a}, \mathrm{b}}$ & Std. Deviation & 11.662 \\
Most Extreme & Absolute & .128 \\
Differences & Positive & .122 \\
& Negative & -.128 \\
Test Statistic & .128 \\
Asymp. Sig. (2-tailed) & $.145^{c}$ \\
a. Test distribution is Normal. & \\
b. Calculated from data. & \\
c. Lilliefors Significance Correction. & \\
\hline
\end{tabular}

Sumber: Output SPSS 25

Uji normalitas data menunjukkan nilai dari sig 2-tailed yakni sebesar 0,145 dengan nilai signifikansi sebesar 0,05 . Sehingga 0,145 lebih besar dari 0,05, yang dapat diartikan bahwa data nilai posttest pada kelas eksperimen berdistribusi normal dan pengujian data selanjutnya dapat menggunakan uji statistic parametric.

\section{Peningkatan Nilai Pretest-Posttest}

Pengujian peningkatan nilai ini menggunakan uji $\mathrm{N}$-Gain. Uji ini memiliki tujuan yakni untuk mengetahui peningkatan antara nilai pretest dengan puttest siswa. Pengujian ini dilakukan pada kelas eksperimen. Tabel dari uji $\mathrm{N}$-Gain dapat dilihat pada tabel 5.

Tabel 5. Hasil Uji N-Gain

\begin{tabular}{lllll}
\hline Kelas & $\begin{array}{l}\text { Nilai } \\
\text { Pretest }\end{array}$ & $\begin{array}{l}\text { Nila } \\
\text { Posttest }\end{array}$ & $\begin{array}{l}\text { N- } \\
\text { Gain }\end{array}$ & $\begin{array}{l}\text { Interpr } \\
\text { etasi }\end{array}$ \\
\hline $\begin{array}{l}\text { Eksperim } \\
\text { en }\end{array}$ & 27,27 & 72,22 & 0,69 & $\begin{array}{l}\text { Sedan } \\
\mathrm{g}\end{array}$ \\
\hline
\end{tabular}

Dari tabel tersebut didapatkan hasil dari $\mathrm{N}$-Gain yakni sebesar 0,69 dengan interpretasi peningkatan sedang. Peningakatan nilai ini disebabkan ketertarikan peserta didik dengan model pembelajaran inkuiri yang belum pernah mereka peroleh, seta dikolaborasikan dengan media petaku yang menambah antusias siswa terhadap pelajaran menjadi meningkat. Media petaku ini dikaitkan dengan kegiatan yang sering mereka lakukan di daerah sekitar, sehingga akan menambah pengalaman belajar peserta didik. Hal yang sama juga dikemukakan oleh Andiasari (2015) bahwa pembelajaran yang bermakna untuk siswa dapat diciptakan melalui kejadiankejadian yang ada atau berkaitan dengan kehidupan sehari-hari siswa. Maka 1 lari itu terdapat peningkatan antara nilai sebelum dan sesudah penerapan model inkuiri dengan bantuan media petaku.

\section{Ketuntasan B1 lajar Individual}

Uji ini digunakan untuk mengetahui apakah pengaplikasian model inkuiri dengan bantuan media petaku mencapai ketuntasan Telajar setiap individu sehingga memenuhi kriteria ketuntasan dengan yang diterapkan oleh sekolah yakni 65. Uji ini dengan menggunakan program SPSS 25. Pengujian parametric pada satu sampel dapat dilakukan dengan uji One Sample T Test. Hasil dari uji ketuntasan belajar individual sebagai berikut. Tabel 6. Hasil Uji One Sample T Test

\section{One-Sample Test}

Test Value $=65$ 


\begin{tabular}{|c|c|c|c|c|c|c|}
\hline & \multirow[b]{2}{*}{$\mathrm{T}$} & \multirow[b]{2}{*}{ Df } & \multirow{2}{*}{$\begin{array}{l}\text { Sig. (2- } \\
\text { tailed) }\end{array}$} & \multirow{2}{*}{$\begin{array}{c}\text { Mean } \\
\text { Differe } \\
\text { nce }\end{array}$} & \multicolumn{2}{|c|}{$\begin{array}{c}95 \% \\
\text { Confidence } \\
\text { Interval of the } \\
\text { Difference } \\
\text { Uppe }\end{array}$} \\
\hline & & & & & Lower & $r$ \\
\hline Nilai & 3.716 & 35 & .001 & 7.222 & 3.28 & $\begin{array}{r}11.1 \\
7\end{array}$ \\
\hline
\end{tabular}

Sumber: Output SPSS 25

Dari tabel 6 tersebut didapatkan hasil sig. (2-tailed) yakni sebesar 0,001 menggunakan taraf signifikasi 0,05. Maka 0,01 $<0,05$ dan dapat ditarik kesimpulan rata-rata nilai posttest siswa yang dikenakan model inkuiri berbantuan media petaku mencapai Kriteria Ketuntasan Minimal (KKM) secara individual.

\section{Pengujian Ketuntasan Belajar Klasikal}

Tujuan dari pengujian ini untuk mengetahui hasil dari aspek pengetahuan, yakni hasil belajar siswa yang dikenakan model inkuiri dengan bantuan media petaku mencapai 75\% ketuntasan klasikal dari jumlah siswa. Dengan aplikasi Microsoft Excel 2016 sebagai berikut.

Tabel 7. Hasil Uji Z

\begin{tabular}{ccrr}
\hline $\mathbf{X}$ & $\mathbf{N}$ & $\mathbf{z}$ hitung & $\begin{array}{c}\mathbf{z} \text { tabel } \\
(\mathbf{a}=\mathbf{0 , 0 5})\end{array}$ \\
\hline 29 & 36 & 0,770 & 1,65 \\
\hline
\end{tabular}

Dari tabel di atas didapatkan nilai $\mathrm{Z}$ hitung yakni 0,770 , sedangkan nilai $-Z$ tabel dengan nilai $\mathrm{a}=0,05$ yakni $-1,65$. Maka $0,0770>-1,65$ sehingga didapat kesimpulan bahwa rata-rata nilai posttest siswa setelah dikenakan pemberian media petaku dengan dikolaborasikan model inkuiri dapat mencapai ketuntasan klasikal.

Penelitian yang selaras juga dikemukakan oleh Wulandari (2016) yang didapatkan bahwa model pembelajaran inkuiri dapat meningkatkan hasil belajar siswa pada kinerja kelompok dan hasil tes tertulis. Dalam penelitian ini terdapat dua siswa yang tidak tuntas dalam pembelajaran dengan jumlah keseluruhan siswa sebanyak 24. Sedangkan persentase ketuntasan klasikal yakni sebesar $91,67 \%$. Berdasarkan penjelasan tersebut, maka dapat ditarik kesimpulan bahwa model inkuri efektif terhadap peningkatan hasil belajar siswa pada pelajaran matematika.

\section{Pengujian Aktivitas Siswa}

Pengujian aktivitas siswa ini dengan uji Mann Whitney atau dengan Statistic Non
Parametric. Tujuan dari uji ini yakni untuk mengetahui apakah terdapat perbedaan antara aktivitas belajar kelas eksperimen dan kelas kontrol. Indikator dalam aktivitas belajar siswa yang digunakan sesuai dengan yang ditulisian oleh Lestari dan Yudhanegara (2018: 99) yakni: 1) menyatakan pendapat; 2) mengajukan pertanyaan; 3) menanggapi pendapat orang lain; 4) pengerjaan tugas dengan baik; 5) ikut andil dalam pelaksanaan diskusi; 6) keterlibatan dalam penyelesaian masalah; 7) ikut berpartisipasi dalam diskusi secara kelompok; 8) berani tampil di hadapan teman lainnya. Hasil dari uji Mann Whitney dapat dilihat pada tabel 8.

Tabel 8. Hasil Uji Mann Whitney

\begin{tabular}{lr}
\hline \multicolumn{2}{c}{ Test Statistics $^{\text {a }}$} \\
\hline \multicolumn{3}{c}{ Aktivitas Siswa $^{2}$} \\
Mann-Whitney U & 380.500 \\
Wilcoxon W & 845.500 \\
Z & -2.082
\end{tabular}

Asymp. Sig. (2-tailed) $\quad .037$

a. Grouping Variable: Kelas

Pada tabel1 uji Mann Whitney didapatkan nilai Asymp. Sig. (2-tailed) sebesar 0,037 dengan penggunaan taraf signifikasi 0,05. Maka 0,037 < 0,05 dan didapat kesimpulan bahwa setelah penerapan model inkuiri berbantuan media petaku lebih dapat meningakatkan aktivitas siswa dibandingkan dengan penggunaan model pembelajaran konvensional.

Penerapan model inkuiri dalam pembelajaran di kelas eksperimen dibagi ke dalam beberapa kelompok yang heterogen. Tujuan dari pembagian kelompok ini untuk menumbuhkan interaksi antara satu siswa dengan siswa lainnya dalam satu kelompok. Hal yang sama juga dikemukakan oleh Ulya dan Rahayu (2017) bahwa interaksi serta sikap positif yang terbangun diantara siswa menjadikan ia lebih termotivasi dalam belajar matematika.

\section{KESIMPULAN}

Dari hasil penelitian diperoleh bahwa model pembelajaran inkuiri dengan bantuan media petaku dapat meningkatkan hasil belajar peserta didik pada pelajaran matematika yang dibuktikan dengan hasil nilai $N$-Gain yakni sebesar 0,69 dengan peningkatan pada kategori sedang. Selain itu model ini juga efektif digunakan dalam pembelajaran, dikarenakan model ini 
mencapai kriteria ketuntasan minimal yang diterapkan oleh sekolah, serta dapat memenuhi ketuntasan klasikal yakni lebih dari $75 \%$ siswa tuntas dalam pembelajaran. Model inkuiri yang dikolaborasikan dengan media petaku ini juga dapat meningkatkan aktivitas belajar siswa pada kelas eksperimen dengan n11ai sig 2-tailed $0,037(\propto=0,05)$, dan hasil ini lebih baik dari aktivitas belajar siswa pada kelas kontrol.

\section{DAFTAR PUSTATA}

Andiasari, L. (2015). Penggunaan Model Inquiry dengan Metode Eksperimen dalam Pembelajaran IPA di SMPN 10 Purbolinggo. Jurnal Kebijakan dan Pengembangan Pendidikan. 3(1), 15-20.

Ayuwanti, I. (2016) Meningkatkan Aktivitas dan Hasil Belajar Mateamtika Menggunakan Model Pembelajaran Kooperatif Tipe Group Investigation di SMK Tuma'ninah Yasin Metro. Jurnal SAP. 1(2), 105-114.

Israwani. (2015). Penggunaan Model Pembelajaran Inkuiri Pada Materi Operasi Hitung Bilangan Di Kelas 1 SD Negeri 53 Banda Aceh. Jurnal Peluang. 3(2), 55-64.

Lestari, K. E., dan Yudhanegara, M.R. (2018). Penelitian Pendidikan Matematika. Bandung: PT Refika Aditama.

Majid, A. (2017). Panduan Penilaian Untuk Sekolah Dasar (SD). Jakarta: Rosdakarya.

Organization for Economic Coperation and Development (OECD). (2019). PISA 2018 Result Combined Executive Summaries. Volume I, II dan III.

Rohmah, R. E. N., dan Nur, R. E. (2017). Eksperimentasi Model Pembelajaran Tipe Numbered Head Together Terhadap Hasil Belajar Matematika. Jurnal Ilmiah Pendidikan Matematika. 5(3), 303-312.
Sugiyono. (2016). Metode Penelitian Kuantitatif, Kualitatif, dan R\&D. Bandung: Alfabeta.

Ulya, H., dan Rahayu, R. (2017). Increasing Primary School Students' Attitude Toward Mathematics Though The Implementation of Treffingger Learning Using Dakon Game. International Conference On Education. 1(1). 1-7.

Wulandari, F. (2016). Penerepan Model Pembelajaran Inkuiri Terbimbing Untuk Meningkatkan Hasil Belajar IPA Siswa Sekolah Dasar. Jurnal Pedagogia. 5(2), 267-278. 
21 Praswanti, Bintoro, \& Ulya

This page is intentionally left blank 


\section{Efektifitas Model Pembelajaran Inkuiri Berbantuan Media Petaku Terhadap Hasil Belajar Matematika}

ORIGINALITY REPORT

9

SIMILARITY INDEX
$0 \%$

INTERNET SOURCES
$0 \%$

PUBLICATIONS
$10 \%$

STUDENT PAPERS

PRIMARY SOURCES

Exclude quotes

On

Exclude bibliography

On
Exclude matches

$<3 \%$ 